\title{
Escrevendo e lendo sobre a identidade, a diferença e a solidão
}

\section{Writing and reading about identity, difference and loneliness}

https://doi.org/10.34112/2317-0972a2016v34n66p13-29

\section{CARLOS SKLIAR ${ }^{1}$}

Resumo: Talvez o único sentido, a única razão da escrita e da leitura seja escrever. Sem ter razões para fazê-lo. Não escrever nem ler para assumir uma posição a partir da qual ver o mundo, nem para autorizar que outros assumam essas ou outras posições. Na escrita e na leitura não há outra razão senão o amor e o desamor pelas palavras, a paixão e o desassossego pelas palavras, a atração e a repulsa pelas palavras. Se a escrita e a leitura já não são o que eram, trata-se de se perguntar se ainda vale a pena pensar o que era a escrita (e o que era a leitura) que agora não é, o que é essa escrita (e o que é essa leitura) que agora, sim, é. Com Manoel de Barros, Clarice Lispector, Fernando Pessoa e Stefan Zweig, entrelaça-se neste texto a escrita (e a leitura) ao pensamento sobre identidade, diferença e solidão.

PALAVRAS-CHAVE: Escrita; leitura; identidade; diferença; solidão.

ABSTRACT: Perhaps writing is the only reason for writing and reading. There should be no reasons for having to do it. We should not write or read to take a stand in the world nor should we write to entitle others to take their stands. Writing and reading should be guided by love and lovelessness of the words, by passion and restlessness of the words, attraction and repulsion of words. If writing and reading are no longer what they used to be, maybe we

1. Consejo Nacional de Investigaciones Científicas y Tecnológicas de la Argentina (CONICET) e Facultad Latinoamericana de Ciencias Sociales (FLACSO), Buenos Aires, Argentina. 
should wonder whether it is even worth thinking about what writing used to be (and what reading was) now that it is no longer the same, or what writing is (and what reading is) now. In this paper, with Manoel de Barros, Clarice Lispector, Fernando Pessoa and Stefan Zweig, writing (and reading) is brought closer to the thought of identity, difference and loneliness. KEYWORDS: Writing; reading; identity; difference; loneliness.

\section{INTRODUÇÃO: A ESCRITA E A LEITURA COMO FIGURAS DO HUMANISMO}

Talvez o único sentido, a única razão da escrita e da leitura seja escrever. Sem ter razões para fazê-lo; não escrever nem ler para ser alguém na vida, nem no futuro, nem a posteriori. Não escrever nem ler para assumir uma posição a partir da qual ver o mundo, nem para autorizar que outros assumam essas ou outras posições. Nem para avançar na vida, nem para retroceder; nem para ser melhor ou pior pessoa.

Na escrita e na leitura não há outra razão senão o amor e o desamor pelas palavras, a paixão e o desassossego pelas palavras, a atração e a repulsa pelas palavras.

Mas a escrita e a leitura já não são o que eram. O que não está nem mal, nem bem. Apenas se trata de se perguntar se ainda vale a pena pensar o que era a escrita (e o que era a leitura) que agora não é, o que é essa escrita (e o que é essa leitura) que agora, sim, é. $\mathrm{O}$ que estaria mal seria pensar que assim são, naturalmente, as coisas.

Já sabemos o que provoca a domesticação através da linguagem. Uma das perguntas que, acredito, vale a pena se fazer é aquela do humanismo relacionada com a escrita e a leitura. Essa pergunta encontra aqui - por certo fortemente inspirada por algumas ideias do filósofo Peter Sloterdijk - duas direções possíveis: a noção de comunidade que a escrita e a leitura produzem e a afirmação da escrita e da leitura como norma. Ambas as ideias provêm, com efeito, da história do humanismo, ainda que em diferentes tempos.

De fato poderíamos identificar a história do humanismo com a história da escrita: a escrita como um tipo de carta universal que vai passando de geração a geração graças a um pacto secreto entre emitentes e destinatários, originais e cópias, um vínculo para não encerrar-se, para poder realizar travessias próprias e alheias. Temos aqui uma ressonância daquele Nietzsche que procurava transformar o amor pelo próximo - esse amor tão imediato, tão religioso, tão mesquinho - em um amor pelas vidas outras, alheias, desconhecidas. E essa transformação era possível, e ainda é, graças à escrita e à leitura. 
A escrita, então, como convite para ir além, para sair, um convite para abandonar o relato repetido, essa identidade do um mesmo como centro do universo, a escrita e a leitura para nos afastar da nossa vida convencional.

Digamos que um espectro comunitário está na base de todos os humanismos, uma sorte de comunhão em harmonia. Antes, muito antes da chegada do que hoje chamamos o Estado, ao Estado Nacional, saber ler e escrever suporia:

Algo assim como ser membro de uma elite misteriosa. Em outro tempo, os conhecimentos de gramática eram considerados em muitos lugares como sinônimo de magia. De fato, já no inglês medieval derivou da palavra grammar ou glamour. Para aqueles que sabem ler e escrever, também outras coisas impossíveis lhes parecerão simples. Os humanizados não são, em princípio, mais do que a seita dos alfabetizados; como outras muitas seitas, também nesta se manifestam projetos expansionistas e universalistas. (SLOTERDIJK, 2006, p. 24) $)^{2}$.

Destacamos algumas palavras desse fragmento, por exemplo: elite, mistério, magia, glamour, seita. É imediata a sensação de um mundo divido em função do privilégio da escrita e da leitura. O que não faz mais do que nos devolver à crença platônica em uma sociedade na qual todos os homens são animais - o que não deixa de ser certo mas onde alguns criam outros e estes outros serão, sempre, os criados. Para dizer de outra maneira: os animais que leem e escrevem educam os animais que não o fazem.

Esse humanismo de Estado é a origem da imposição da leitura e da escrita obrigatória: os clássicos, o cânone, o valor universal dos textos nacionais. Porém, as ideias do humanismo já não podem contra a época atual; não podem, não cabem, são anacrônicas. Certamente, porque também a escrita e a leitura têm se transformado em mercadorias e já não requerem leitores ou escritores amantes ou amigos, mas consumidores.

1. A escrita, o escrevendo. A leitura, o lendo.

E se fosse verdade que as casualidades não existem: como entender, então, que começo a escrever-te no preciso momento em que querias ler-me? Carlos Skliar

2. Os textos em espanhol deste texto foram traduzidos livremente pelo autor. 
A questão é, portanto, repensar a escrita e a leitura. O que já sabemos e o que não sabemos. Antes, durante e depois da educação. $O$ pedido da escrita e da leitura. Pedir a escrita e a leitura, mas predicar sem demasiados exemplos.

Escrever e ler têm se tornado ações tão evidentes que já parecem não haver espaço para continuar pensando. Em termos educativos é difícil, senão impossível, diferenciar o moral do útil, do necessário e do imprescindível. Em termos culturais também o é. Como pôr a escrita e a leitura no meio? Quais escritas, quais leituras? As breves, as que respondem a demandas, as que se relacionam com o trabalho mas não com a criação ou com a singularidade ou com a subjetividade ou com a intimidade? Todo escrever e todo ler é equivalente?

Educar é pôr no meio a escrita e a leitura. Fazer coisas, juntos, entre nós e entre outros. Pôr a escrita e a leitura no meio é pensar algo distinto do registro, do arquivo, o retorno do aprendido ou como um código fechado para a avaliação. Pois, bem: não se trata da escrita nem do escrever, mas, do escrevendo, não se trata da leitura nem do ler, mas, do lendo.

O que é, o que poderia ser: escrevendo, lendo? Trata-se de uma pergunta diferente daquela: o que é escrever?, e também daquela: o que é a escrita? Sobre essas duas últimas aparências da pergunta já temos suficiente informação, mesmo que seja ambígua e contraditória e devamos pensar, ainda, entre a racionalidade pedagógica e a racionalidade literária.

Temos de perguntar pela escrita através de algumas práticas, mas marcando esse escrevendo como o único tempo possível, no instante em que ocorre, na sua duração. O que sabemos é que a escrita é pedida. Não pode deixar de nos surpreender, mesmo em sua aparente habitualidade, essa relação entre escrita e pedido. Por vários motivos: em princípio porque isso sugere que o escrito tem somente um valor de resposta; em seguida, porque dá a sensação de que - de ser uma resposta ou de ter apenas essa propriedade - não sabemos do que com exatidão: a uma pergunta escrita, ou um texto lido, a um saber entregue, a uma informação solicitada, a uma necessidade de completar um objetivo, ao desejo de que alguém se expresse com propriedade?; e por último: porque se a escrita fosse reduzida a um mecanismo de intercâmbio estreito, ficaria confinada ao exercício de sua correção ou de sua adequação e, portanto, à lógica do que é apropriado ou inapropriado.

A escrita é pedido, e também é a sombra ou apenas a superfície daquilo que se tem dado. Essa escrita pedida e avaliada não diz nada da escrita nem do ensino, o que faz esta análise tomar uma direção completamente diferente. O que deveríamos 
fazer é pensar o modo como nos relacionamos com a leitura e a escrita. E que a nossa leitura é cada vez mais escassa, cada vez menos literária e mais midiática; fazemos pactos cotidianos em relação à brevidade e à fragmentação ou redução dos textos; sentimos desprezo pela escrita criativa, ensaiada, livre de espírito; o exílio das bibliotecas nos confins dos espaços escolares; e - o que me parece mais trágico - certo esquecimento do passado.

Criticamos os outros porque não escrevem ou não leem, ou porque não escrevem com suas próprias palavras, ou porque não se soltam, porque não escrevem de um modo soberano, não tecem seu próprio discurso ou o discurso resultante nos é incompreensível. Mas: como seria possível fazê-lo? O que possibilitaria aos outros escreverem e lerem algo que valesse a pena?

Ensinar a escrita é mostrar a escrita, é vê-la, revelá-la, se entregar a uma gestualidade que não reconhece princípio, duração, final: a escrita é esse mistério que permanece escrevendo a si própria.

Em A palavra herdada, Eudora Welty (2012) propõe um exercício da memória: de onde vêm os primeiros sons, as primeiras leituras, o gesto de escrever? O que torna possível a escrita como início de uma ação cujo final se ignora? Como se relacionam as experiências de escutar e guardar as palavras, de ser lido e, talvez, escrever, de olhar para o pequeno, para aquilo que não tem nome?

Ninguém sabe como se aprendem as propriedades da língua, quais trajetórias ou travessias se tornam acertos ou desacertos na escolha de uma palavra. Welty lembra, por exemplo, o poder da escuta durante a sua infância: escutar as canções; escutar sua mãe cantando dia e noite; escutar a primeira vez em que lhe foi oferecida a leitura. Desde a primeira vez que leram para mim, e desde que comecei a ler por mim mesma, jamais existiu uma só região que não tenha ouvido (WELTY, 2012, p. 32). Lembra, também, a aprendizagem de seu olhar: o olhar no sentido de aprender a compreender ou, melhor ainda, de se dar conta; aprender a duvidar, a perceber a diferença entre as luzes e os volumes, as superfícies e as trevas. Lembra, finalmente, o encontro com a sua própria voz: a emergência do relato, o descobrimento do dizível, a paixão por contar: a voz restabelece ali a corporalidade, a gestualidade no modo de significar. O discurso já não é ali uma escolha na língua, ou operadores lógicos, senão uma atividade de um homem que realmente está falando (MESCHONNIC, 2007, p. 148).

Escutar, aprender a ver, encontrar uma voz: tal a irrepetível sequência, a sustentada desordem na qual a escrita encontrou um lugar onde se estender, fazer-se matéria e logo, se for o caso, dar-se a ler. 


\section{OS ARgumentos PEDAGógicos E OS ARGUMENTOS LITERÁrios PARA O ESCREVENDO E O LENDO}

Escrever é como não haver morrido. Ao contrário: há demasiada vida quando as palavras recorrem os lugares abandonados, as obscuras passagens onde o corpo não passa, a impossível claridade de uma tarde quando ainda é madrugada. Mas a vida significa tantas coisas: a casa solitária, o exilio de cada homem, o abismo no qual assomamos, a voz que é o fio mais débil e, sobretudo, os olhos que se abrem e começam a desejar o que nunca viram. Dizer o que já se disse, porém com outras palavras. Encontrar o segredo que jamais nos confessaram.

Carlos Skliar

Escrevendo poderia significar contar experiências próprias com palavras próprias, mas não parece que sejam bons tempos para isso, quer dizer, não existe a certeza de que a escrita seja um modo evidente e eficaz para esse propósito. Aqueles que transitamos pela vida acadêmica somos reprimidos ao escrever nossas próprias experiências, em vez de investigar ou estudar a realidade dos outros; em nossas próprias palavras, em vez de nos adequarmos às palavras da moda.

O discutível modelo da escrita academicista tem se instalado vertical e transversalmente no mundo educativo como se houvesse alguma virtude nisso. Ensaiar, narrar ou contar não parecem ser registros amigáveis nos dias atuais. Portanto, não podemos dizer que o pedido seja razoável quando a atmosfera na qual se espera que algo aconteça com a escrita e com a leitura tem se tornado turva ou, diretamente, asfixiante.

Trata-se apenas de escrever o que nos acontece com nossas próprias palavras. Mas, isso é literatura, diriam. E, eu, respondo sim, sem dúvida. Mas, não somente. No pedido por escrever não cabem muitas outras opções: ou se trata de um pedido amarrado em tradições e racionalidades pedagógicas ou, por clara oposição, o pedido é literário, isto é: tocar o limite da linguagem, tocar suas formas, procurar a metáfora, a imagem, privilegiar os instantes para que durem além do possível.

Trata-se de um pedido da escrita do outro. Sem o outro, a escrita está despojada de alteridade. E despojada de alteridade não há escrita. A escrita é um ato propósito que se dirige ao outro para que se complete sua ficção, ainda que no incompleto da língua. A palavra de alguém acaba por não ser compreendida até que suceda a 
palavra do outro: "[...] escrever é deixar que outros fechem por si mesmos a própria palavra de alguém, e o escrever não é mais que uma proposição da qual nunca se sabe a resposta" (BARTHES, 2003, p. 376).

Se é verdade que procuramos respostas à pergunta de por que escrever, há aí uma batalha entre as razões pedagógicas e as razões filosóficas e literárias. Já não basta dizer que escrever é importante para o amanhã, que escrever serve para o futuro, que escrever serve para o trabalho ou para a continuidade no estudo, que escrever garanta uma ou outra posição de privilégio. Escrevendo é no presente, não no futuro. Escrever escrevendo, sim. Mas, por quê? E quem responde?

As pedagogias mais formais da escrita tendem a uma argumentação utilitária e suas didáticas são modos de convencer alguém ou todos para que escrevam no contexto de um saber já pré-estabelecido relativo ao funcionamento da língua ou do texto. Outras pedagogias talvez mais recreativas, abusam de um expressionismo sem fim onde a leitura inexiste. Em certos casos, a escrita não aparece senão como uma contrapartida diagnóstica de um ensino anterior ou como uma maneira de registro que desaparecerá no dia seguinte. Em outros casos, é um meio entre o conhecimento anterior, precário, e o conhecimento sucessivo, superior. Às vezes, sucede o jogo do escrito, mas apenas como um tipo de desinteresse mediante a impotência de não saber como deixar a escrita liberada a sua própria sorte. Outras vezes, ocorre como prótese de uma comunicação que, em boa parte dos casos, poderia ser resolvida de outros modos.

A argumentação literária da escrita não fica por fora da escrita, não é exterioridade, porém intimidade, uma intimidade que pode se encontrar na revelação mesma presente nos textos dos escritores. Por exemplo: se está escrevendo para defender a solidão em que nos encontramos (por exemplo, Zambrano, Duras); porque de outro modo o mundo seria o que é: insuportável (Pamuk); porque é a única invenção que serve para nos distrair da morte (Elytis); para tentar reparar uma ferida (Pizarnik); para não se deixar surpreender jamais pelo abismo (Cisoux); para saber escrever, porque nunca se sabe escrever (Banville, Neuman); para dissimular a incapacidade de fazer outras coisas ou por não querer fazer nenhuma outra coisa (Vila-Matas); não para compreender, mas incorporar (Barros); para seguir sendo si mesmo, mas não escrevendo o mesmo (Bernhard); para fazer durar o instante (Szymborska, González) etc.

Sabemos da existência de didáticas que dão conta de suas razões pedagógicas e que fazem escrever porque há que fazê-lo ou porque é importante para amanhã, ou 
porque sem a escrita ninguém poderá ser alguém. Mas é possível imaginar didáticas da escrita cujo centro se encontre inexoravelmente na morte, na última palavra, no enfado, na dificuldade de suportar o mundo, na alteração do real, na solidão, no desespero?

A pergunta segue sendo a mesma diante de cada pessoa nova, desconhecida, anônima ou diferente à qual pretendemos oferecer a escrita. Essa pergunta não é "o que é a escrita?", mas, sim, "como chegamos a ela?" Não ir à escrita, porém chegar a ela, deixando de lado as boas razões que assistem às boas - e falsas - consciências, não esquecendo nunca das más razões, insistentes e inevitáveis, que anunciam a escrita no estremecimento, no temor, na sacudida, no sobressalto, o inconfessável. Aquém e além do texto - que sempre será incompleto, que necessitará de leitores, sobre o qual nunca se darão por satisfeitos - escrever é como ter chegado ao meio de nosso próprio corpo. E é aí que se torna puro gesto.

\section{As QUATRO Formas DO ESCREVENDO E DO LENDO: A IDENTIDADE, A DIFERENÇA, A INTIMIDADE E A SOLIDÃO}

Ler ao revés é deter o tempo que nos designa este mundo e impedir que a máquina utilitária do universo siga seu caminho de massacres. Ler é deixar de fazer ruído. Ler é apoiar o corpo em um tempo que não vivemos, para poder vivê-lo. Ler é livrar-se da tirania opaca de um único tempo. Ler é esse instante no qual a conversação com os mortos se torna pura vida. Ler é a pausa que pode tornar mais largo o universo. Carlos Skliar

\subsection{A identidade do pequeno, A Diferença da infânCia e A} Solidão do poeta: Manoel de Barros

O pequeno, o ínfimo, o que se quebra por nada, aquilo que é inútil, sem serventia, o que dura pouco menos de um instante que já é mínimo, o que desfaz a civilização do ouro e a blasfêmia; inclusive o que não se lembra demasiado, o ímpar, o insuficiente, o sapato solto sem cadarços, o incompleto, o débil, a maçã meio comida, a fragilidade do tempo, da sílaba e da areia; o dócil, o que não se pronuncia porque ainda não é palavra, o que não se cala porque por hora não é silêncio, a árvore ou a flor ou uma criança em desamparo: este é o mundo. 
$\mathrm{O}$ mundo que inventa o que não se descobriu, o que nega passagem às bestas da guerra, o que abre o idioma com voz suave e ali confessa seu inválido segredo, $o$ que ama o canto de uma página, o que contempla sem dar explicações, o que não zomba do homem desprezado nem remove cizânia, a ferida de um pássaro comum, o mundo da criança rejeitada por seus pais, o dos loucos cuja lucidez espanta.

O mundo do pobre diabo, o da estrela apagada, o de tudo aquilo que de verdade importa e que não tem espessura nem relevância alguma; a repetição da água até converter-se em outras coisas em sua chegada ao oceano, o jogo sem prêmios nem castigos, a fixação de uma trepadeira em uma parede amarela. Enfim: todas aquelas coisas que não têm nome e que, como dizia o poeta brasileiro, são as mais pronunciadas pela infância.

É no ínfimo - diz Manoel de Barros (2010) - onde se aprecia a exuberância - tão irrelevante - do pequeno.

Te perguntas, então, o porquê da devoção que têm pelas tumbas as mariposas de manchas vermelhas, te interrogas sobre o lado da noite que primeiro se umedece, te preocupas com o modo como as violetas preparam o dia para morrer mais tarde, afirmas que o esplendor da manhã não pode ser aberto com faca alguma, estás convencido de que tudo aquilo que não conduz a nada, isso mesmo, é o que serve para a poesia.

Deveríamos desaprender, escreves, que é o contrário de saber algo, e te resulta de imediato indiferente já havê-lo conhecido.

Desaprender pelo menos oito horas por dia para adquirir os princípios fundamentais do mínimo, a saber: que é um privilégio não saber quase nada, que há de antepor o primordial ao fundamental, que tudo que é inútil serve para a poesia, que gostaríamos de tomar banho de rio, que há de inventar-se para conhecer-se, que se devem utilizar palavras por sua entonação e não por seu significado, que é certo que os cristais estilhaçados em mil pedaços se reúnam mais tarde ou mais cedo no sorriso de uma criança, que duas nuvens não compõem a mesma chuva e que, quiçá, haverá de ter a preguiça justa para nunca permanecer muito tempo sério.

Porém, o mínimo, o ínfimo, o pequeno, não é a solidão, mas o solitário: a pátria dos gestos sozinhos, fragmentários, que não conformam um sentido nem de princípio nem de final, nem de vertigem nem de serenidade, nem de memória nem de esquecimento: as minimezas ocorrem, como ocorrem os peixes de cores cambiantes, como as ruas breves que não oferecem sinais ao transeunte, como as nuvens dissipadas diante do primeiro vento, como uma chuva em limiar que acaba 
por não chover-se, como uma ideia qualquer nada pretensiosa, como uma página em branco que bem poderia ter sido escrita, ou vice-versa.

Pois estão sozinhos os guarda-chuvas perdidos, os olhares que não se viram, $o$ declive da montanha interrompido pelas ervas crescidas, as carícias no ar que não alcançaram outro corpo, a chamada à porta errada, o abraço de uma criança órfã, a passagem do trem pela estação perdida, a enfermidade do som, o delírio que não é considerado sensatez, o instinto abandonado no altar do argumento.

E toda a poesia a ponto de ser escrita e que ninguém, por preguiça ou por descuido, jamais poderá escrever, nunca.

3.2. A identidade DA ESCRita, A DifERENÇA Do "SiM", E A SOlidẽo da VOZ: CLARICE LISPECTOR

Se é certo que tudo no mundo começou com um sim, se é verdade que um átomo diz sim para outro átomo e assim começou o mundo, então a solidão é afirmação, não se inscreve a partir da enunciação do nome de cada um, mas da indefinição de um ser que grava e apaga em cada linha, morte e ressureição de uma escrita talhada no corpo.

Havias gostado tanto de escrever uma história que começaste com "Era um $v e z$ ”, porém não era uma fábula para crianças. E iniciaste novamente a formular as palavras seguintes: "Era uma vez o amor", "era uma vez o erro", "era uma vez a paixão". Te parecia impossível, porque as histórias necessitavam do ardor do sangue e dessa pena tão remota, tão alheia como própria.

Então, disseste, escreveste: “Era uma vez um pássaro, Deus meu." (LISPECTOR, 1973, p. 13).

Para ser alguém, há que ser o outro dos outros, a pura confusão de identidade, a memória que se esquece de si diante do esplendor do mundo. Ninguém pode nomear-se a si mesmo sem ocultar uma grande ausência de rostos. Ninguém pode ser capaz de toda capacidade.

A única técnica - ai, essa expressão mortuária - é a humildade: a absoluta consciência de que alguém é totalmente incapaz e que terá de aproximar-se das coisas com o sigilo absoluto da mirada limpa.

Se te aproximares do volume excessivo dos nomes, as coisas sairão disparadas.

Teria de aproximar-se com a suave ignorância, com a frágil tentação do desconhecimento: abrir uma porta e, simplesmente, olhar. Olhar o sol que nunca vimos 
antes, o das três da tarde. Olhar o pássaro que se transforma em águia. Olhar a dor sem precaução nem alegorias. Olhar o resultado da mentira. Olhar uma sombra maior que a tua estatura.

Somente assim - e ainda assim - não totalmente seguro, não totalmente certo - haveria escritura: o olhar conserva algumas imagens que existem e outras que nunca existiram, e se escreve também lembrando alguém do que ainda não viveu.

Escrever, Clarice, é não saber o que continua. Buscar o que segue à escrita é como deixar emergir uma palavra utilizando-a como isca: que outras palavras virão, se é que vêm? Ou o que virá é o nada?

Outros escreveram a exasperante totalidade do tudo, outros nomearam o mundo com um punhado efêmero de sons. Porém: o que é mais revelador, o que revela o que: o tudo ou o nada?

Te é impossível a ingenuidade frente à totalidade, porém te é possível por acaso a inocência diante do que parece vazio, nulo. Olhar com inocência, sim, como se esse olhar e essa inocência fossem a textura íntima da solidão; a solidão difícil e paciente, a que ofusca a fragilidade do desejo, a que conhece o inferno da paixão, a que reconhece suas próprias dores e se ruboriza pela ansiedade de fazê-los esfumaçar-se.

Escrever, Clarice, é prolongar o tempo. Encontrar o tempo no interior do tempo. Fazer com que os segundos sejam partículas, milímetros; trazer fios de carne no centro do tempo metálico; permanecer em vez de escapulir; não deixar que as horas passem, mas fazer com que passem palavras nas horas.

Escrever no espaço que deixam as teclas simultâneas de um piano, negando-se o sentido antes do tempo, com a paciência do amor e o amor da paciência.

Querer escrever com a pele, mas ter que escrever com as palavras, apesar das palavras: "Era uma voz, Clarice".

3.3. A identidade do múltiplo, a diferença do Vazio, e A Solidão maiúscula: Fernando Pessoa

Para que escrever senão para fazê-lo melhor?

Mas também: para poder ser o pouco que acreditas ser, por mais sem graça e pequeno e nada que sejas. Para não deixar de escrever, ainda que depreciando-te na escrita. Para seguir consumindo o veneno, desapontar o vício necessário e inoportuno. Para perder-te, sem alegria, sem desembocadura, sem regresso algum para o oceano. Para ter uma visão do imperfeito e do fracassado. 
E Pessoa: para que escreve?

Ninguém pode abdicar de seu próprio castigo: escrever a escritura insegura, como quem toma ar e respira um pouco melhor, sem que a enfermidade tenha sido curada.

Qual enfermidade, qual afogamento?

A da insalubre perda da doçura. A falta de entusiasmo. O desinteresse pela verdade. Pensar tanto. Ser a própria margem da resignação. Querer dormir e saber que é uma ficção o leito, a parede, a tinta, a sombra.

Escrever, às vezes, porque não há nada a dizer.

E encontrar o sentimento em tudo o que não está sentindo: escrever no tédio substancial do isolamento, escrever como solidão isolada.

Distrair-se do viver. Talhar-se à imagem e semelhança da própria solidão.

Apenas as conversações dos sonhos com os amigos imaginários adquirem espírito e relevo. $\mathrm{O}$ resto é querer dormir e não poder dizer nada, esfumaçar-se diante de um espelho vazio.

Pois nada chega a nenhuma parte, e a abstenção do escrever é nobre: todo o escrito não passa de uma sombra grotesca da palavra sonhada.

Escrever porque é impossível conhecer.

Também é uma enfermidade não saber dizer o que se vê, não poder dizer o que se pensa. Haveria de fazer o esforço para tornar real a vida impronunciável: como o fazem as crianças, que transformam o que não pode ser transmitido em percepções literárias.

Mas se Pessoa se pergunta por si mesmo, se farta-se de si, se desconhece, se cansa da vida e pretende o absurdo: não abandonar a existência, porém deixar de sequer haver existido.

Entre o não existir e o nem sequer haver existido: uma desolação que se cura, escrevendo-a, inutilmente; desejando traçar um caminho feito "a partir de um lugar do qual ninguém parte, para um lugar a que ninguém vai” (PESSOA, 1997, p. 112).

Lês o Livro do Desassossego e te perguntas: para que Pessoa escreveu esse livro?

Para a imperfeição, para defender a inutilidade, rechaçar a vaidade da verdade e trair qualquer possível teoria.

Devia tê-lo escrito, porque, no fundo, não há nada além da tristeza.

Uma tristeza como a do crepúsculo, feita de canções, de renúncias falsas; uma tristeza como um tédio por ter de sentir algo, qualquer coisa, tudo; um amarelo pálido, o som de quem grita dentro de um quarto escuro.

Como o resquício de uma tristeza antecipada. 
Ou como a tristeza por ver chorar uma criança: o horror desprevenido de um coração exausto.

A tristeza definida, indefinida.

Enfim: a tristeza sem causa.

Se nos multiplicássemos em vários fragmentos, se nos fragmentássemos em diversas solidões, quiçá a travessia da vida não fosse tão espantosa ou tão severa ou tão persistente ou tão vã; se fôssemos tantos outros, sem um alguém que nos pense, nem nos reúna, nem nos chame a atenção, talvez pudéssemos sentir, falar ou escrever sobre a solidão de outra maneira: com a voz do desassossego.

$\mathrm{O}$ desassossego, o sabes, pode ser uma das tonalidades da verdade: o corpo se opaca, a alma parece expandir-se para os lados e a voz é uma mescla diluída entre partes de outono, partes de gravidade, partes de esquecimento e partes de abandono. Aquilo que o desassossego busca é uma confissão entre o dizer tudo e não dizer nada, quer dizer, no meio de uma pegada e uma cavidade, no meio do caminho entre a absoluta lucidez e o completo desânimo.

Não, não é uma voz, são tantas vozes: o que se detesta, o que se repugna, o ódio, a ação involuntária que se mescla com o sonho voluntário, a gravidez do nascimento e a sensação de que não se nasceu nem para a ação nem para o sonho. Como se o corpo estivesse em outro lugar e as palavras lutassem ou por sua liberdade ou por sua consternação.

O desassossego como tristeza, sim, que é como uma esperança sem vestígios, sem horizonte. Uma voz peculiar que se pergunta sobre uma solidão que é ao mesmo tempo multitudinária e tão pouca coisa; o insubstancial de uma pronúncia que nada pode contra o singular e o plural, que nada pode contra a fome da voz, e que se submete a uma batalha sangrenta entre a ideia e a carne, entre o conceito e o alarido, entre o normal e o bestial.

Pessoa, que não existe, existe em um quarto quieto, em um quarto solitário, em uma habitação sem números, sem luz, com a incerteza de calar ou proferir o clamor que arde em suas múltiplas solidões.

Pensar com sensibilidade ou sentir com o pensamento? Esta é a questão. Pensar na tepidez do sol até fazê-lo arder, pensar no ritmo do coração até mudar sua vertigem ou sua calma, pensar como viver, evitando a todo custo o ter de viver sob o ditame injurioso do pensamento.

A solidão de Pessoa, essa solidão de um homem inexistente, essa solidão que se derrama sobre setenta e dois homens verdadeiros, aceita tudo, recebe tudo, inclusive 
o que está sobre ela: os deuses mortos, o céu aberto, o destino mudo, a humanidade incerta, as religiões cegas.

Mas, sobretudo, o que essa solidão busca, o que deseja mais do que tudo em sua densidade é compreender: compreender como é possível que outras pessoas existam, que existam almas diferentes que não são de ninguém, consciências estranhas que fazem com que nenhuma consciência seja a única; compreender a semelhança do outro ou desejá-la, porque ninguém, nem sequer Pessoa admite a existência dos demais, essas gentes que apenas transcorrem como uma paisagem, uma paisagem desnudada e só, uma paisagem invisível, entre ruas reconhecidas: "Quanto mais diferente de mim é alguém, mais real me parece" (Ibid., p. 245).

Se navegar é preciso, se o mundo é um imenso oceano à deriva, a única verdade que conta é a exceção: não há normas, não há, e cada um de nós, cada uma de nossas solidões, cada voz que naufraga entre o dizer e o não dizer é a comovedora exceção a uma regra que não existe.

Pessoa é uma regra que não existe.

Pessoa é a mais imperfeita de todas as desejadas exceções que nunca existiram, e que não existirão jamais.

\subsection{A IDENTIDAde DeSCONHeCidA, A DiferençA Viva, A SOlidão} ENQUANTO SILENCIO: STEFAN ZWEIG

Não dizer, ainda.

Os segundos, as horas, as décadas que passam, às vezes não são mais do que um grande segredo amontoado entre as têmporas, o limiar de uma enxaqueca.

É verdade: há algo ali fora que continua, que dura, que toma a extensão de uma vida, de um sonho justo ou de um pesadelo insano, de uma moeda alçada em voo que ainda permanece sobre sua borda, sem tomar decisão alguma.

Há vidas que se desdobram em todas as direções possíveis: saltam, empurram, voam, sopram, se estiram, contraem e bebem; vidas que ocupam inúmeros declives, que entram e saem das coisas como se nada fosse realmente importante e a leveza de todas as brisas as impulsionasse à mercê em um vai e vem sempre distinto.

As palavras, ali, tomam a forma do estrondo e da retratação, nada é definitivo, cada fragmento o é; a cada instante parece mudar de pele, mudar o rosto, apontar o gesto para outra direção. 
A solidão como distração, como a geada que se faz água e logo lama e logo areia e logo pedra e, enfim, outra vez, em uma repetição sem ar, o orvalho da madrugada, o frio seco manhã, a esquálida tepidez do meio-dia, a umidade da tarde, a reclusão do corpo pela noite.

Entretanto há vidas cuja gravidade não está no que se desdobra, porém no que se contém, em tudo aquilo que está a ponto de ser dito e ainda não é pronunciado, vidas que se submetem à ilógica de uma dupla vertigem: a da paixão desordenada - o desejo rugoso, a obstinação da beleza - e a das palavras que não são ditas, que não acontecem, guardadas em sigilosos cofres, sempre pequenos, incapazes de reter a explosão iminente de uma língua que vocifera e cala ao mesmo tempo.

A solidão como confissão: algo será dito, porém mais tarde, algo fundamental, algo que logo - quiçá tarde - muda todo o argumento da obra, algo que não se pode dizer no momento porque nunca há um momento oportuno, algo que não pode imitar o desejo nem seguir como torpe tradução à intensidade do vivido.

Uma superação evidente: viver o que se vive, dizer o que se vive; uma linha perceptível que distingue o rumor incessante no essencial sem insistir em dá-lo a conhecer.

Não seremos matéria de opinião, mas de percepção. Atravessamos o mundo de frente enquanto a vida costuma estar por trás e aos lados.

Damos nomes a tudo o que ocorre, e um roteiro silencioso vai tecendo ao mesmo tempo uma história completamente diferente: desconhecidos que deixam - quase sem querer - sinais ou símbolos imperceptíveis e duradouros, vozes de outros que uivam dentro de nós.

Como se um desconhecido não fosse uma verdade, porém a encarnasse; como se a verdade, sempre, viesse de outra parte.

Contudo, não se trata da verdade última, derradeira, que dá conta de tudo aquilo que não foi visto nem compreendido antes, uma razão lúcida que sobrevém apenas até o fim como lição quieta: é mais bem a decantação de um relato que dá um sentido oblíquo para o passado, uma sorte de terremoto que começou distante daqui e que agora faz tremer toda a pátria do presente.

Alguém te diz que aquilo que pensavas jamais havia sido desse modo. Que o amor não era amor ou que era amor completamente. Que essa dor não merecia o tamanho de tua ferida. Que havia algo pendente entre nós, uma rocha em um vai e vem pedregoso, uma lasca em suspenso, a detenção de alguém em sua memória enquanto o outro continua alterado. 
Um homem recebe uma carta, um documento de quinze ou vinte páginas, folhas escritas com letra débil, exausta. Uma mulher desconhecida escreve a revelação de sua própria vida: é por acaso possível que esse homem não soubesse da existência de alguém para quem foi o argumento de sua vida? É possível que sua existência haja prevenido o sentido de não haver reconhecido a presença iniludível de uma desconhecida?

A escrita se torna, assim, a memória comum de um par de vidas até aqui ignoradas por uma delas, a reconstrução de cada passo que se deu sem saber, o amor que se deu sem amar, a expectativa, o desejo, a espera de um outro sem alguém.

E com a última carta começa outra vida: uma vida ao contrário, daqui para trás, impedida de mover-se para a impunidade dos dias que virão e agora condenada, sujeita, a uma vida que já era sua sem sua presença. A indiferença suprema, voluntária ou não, demente ou não, que confinou outra vida num relato sem nós, pura intimidade sem voz.

Até aqui já é impossível o ocultamente e o silêncio, e aparece de frente a um espelho de décadas pelo qual nunca havia passado antes, como se nada tivesse fixado nessa imagem que era sua, girando o rosto por azar ou indolência ou estupidez, para impedir olhar-se de verdade.

A Carta de uma desconhecida, de Stefan Zweig (2002), mostra até que ponto nossas vidas são relatos cuja autoria está escrita em outra parte, em outro tempo, com outras palavras, quase sem nós.

De onde vêm essas flores que celebram cada aniversário; esse aroma pontual? Onde está o filho que não se conhece e que agora já morreu sem poder voltar atrás? Como fará para continuar uma conversação cujo início não foi escutado? Como fará para avançar, se a verdade que se oferece, a verdade do amor, agora começa a retirar-se como uma sombra bestial por debaixo de cada uma das portas, impedido de gritar, ausente de sua própria criação, de sua própria evidência ignorada?

Não poderá senão olhar, como se ocorresse pela primeira vez, como se nunca tivesse olhado em certa direção, e ver que o jarro azul em cima da mesa, ali onde o homem está lendo a carta de uma desconhecida, já não tem flores, justo hoje, o dia de seu novo aniversário, o dia que compreender todas as vidas presentes e perdidas, o dia em que, de verdade, saberá de que é feito o frio e como é irreparável a morte. 


\section{REFERÊNCIAS}

BARROS, M. Poesia completa. São Paulo: Leya, 2010.

BARTHES, R. El placer del texto y lección inaugural. Buenos Aires: Siglo XXI Editores, 2003.

LISPECTOR, C. Água viva. São Paulo: Artenova, 1973.

MESCHONNIC, H. La poética como crítica del sentido. Buenos Aires: Mármol-Izquierdo Editores, 2007. PESSOA, F. O livro do desassossego. São Paulo: Companhia das Letras, 1997.

SKLIAR, C. No tienen prisa las palabras. Barcelona: Editorial Candaya, 2012. . Isto não é um livro de poemas. Rio de Janeiro: Textoterritório, 2015.

SLOTERDIJK, P. Normas para el parque humano. Madrid: Siruela, 2006.

WELTY, E. La palabra heredada. Madrid: Impedimenta, 2012.

ZWEIG, S. Carta de una desconocida. Barcelona: Acantilado, 2002.

\section{SOBRE O AUTOR}

Carlos Skliar é pesquisador do Consejo Nacional de Investigaciones Científicas y Tecnológicas de la Argentina (CONICET) e da área de Educação da Facultad Latinoamericana de Ciencias Sociales (FLACSO). É Doutor em Fonologia, com Pós-doutorado em Educação pela Universidade Federal do Rio Grande do Sul (UFRGS) e pela Universidade de Barcelona (Espanha). Atuou como professor adjunto na Faculdade de Educação da Universidade Federal do Rio Grande do Sul e como professor visitante em outros países: Universidade de Barcelona (Espanha), Universidade de Siegen (Alemanha), Universidade Metropolitana de Chile, Universidade Pedagógica de Bogotá (Colômbia) e Universidade Pedagógica Caracas (Venezuela).

É autor dos livros de poemas Primera Conjunción (1981), Hilos después (2009), Voz apenas (2011) e Isto não é um livro de poemas (2015); do livro de aforismos e ensaios La intimidad y la alteridad (2006); e publicou também No tienen prisa las palabras (Candaya, 2012) e Hablar con desconocidos (Candaya, 2014).

É autor de vários livros sobre pedagogia e filosofia, incluindo Lo dicho, lo escrito, lo ignorado (Terceiro Prêmio Nacional de Ensaio, Secretaría de Cultura de Nación, 2013), Desobedecer a linguagem (2015) e muitos títulos em parceria, com traduções publicadas em português e no Brasil.

E-mail: skliar@flacso.org.ar

Recebido em 01 de abril de 2016 e aprovado em 28 de abril de 2016. 